\title{
Promoting Scientific Literacy by Using ICT in Science Teaching
}

\author{
Mohammed Salameh Al-Rsa'i ${ }^{1}$ \\ ${ }^{1}$ Al-Hussien bin Talal University, Ma'an, Jordan \\ Correspondence: Mohammed Salameh Al-Rsa'I, Al-Hussien bin Talal University, Ma'an, Jordan. Tel: \\ 962-777-876-786. E-mail: rsaaie@ahu.edu.jo
}

Received: July 12, $2013 \quad$ Accepted: August 12, $2013 \quad$ Online Published: August 30, 2013
doi:10.5539/ies.v6n9p175
URL: http://dx.doi.org/10.5539/ies.v6n9p175

\begin{abstract}
This study aims to identify the way upon which ICT can be employed in science teaching to develop scientific literacy level.

The study has conclude to design a triple learning model (PEA) based on ICT and constructive learning strategy in teaching science through a context which cares for building positive trends of searching for knowledge and increasing scientific literacy level of the students at schools and universities. The PEA model depends on the use of ICT in the teaching of science through the following three requirements:

1. Using ICT in a way that is consistent with the tendencies of the students and their attitudes.

2. Constructing educational content based on the constructivist theory of learning.

3. Providing social learning environment.

Thus, the study recommends the bodies in charge of the educational process to necessarily adopt the project of rebuilding scientific literacy through supplying classrooms and laboratories with ICT supplies as well as training teachers and faculty members in universities on science teaching skills by using ICT based on the Constructivist Theory.
\end{abstract}

Keywords: constructivist theory, ICT, science teaching strategies, scientific literacy

\section{Introduction}

The level of scientific literacy of individuals significantly affects development in the society (Laugksch, 2000), (Adubifa, 2003) and the growing of scientific literacy leads to economic growth and social stability at political and social levels, (Bidokht \& Assareh, 2011).

There is a close relationship between the scientific literacy and cultural renaissance.This relationship may be attributed to the idea that the standard of development of modern societies is based on how much citizens perceive science and technology (Milne, 2007; Al Shibani, 2000). Furthermore, economic boom, development of society, and ability of competition in the era of globalization are based on scientific excellence. This positive change cannot be achieved unless such groups are able to adapt themselves to requirements of scientific movement (Wagner \& Kozma, 2005).

Providing all components of society such as basic kinds of knowledge, whether scientific or technological ones even in a simplified manner, to the commons especially the young generation; has become a key objective in the knowledge society (Adubifa, 2003). Accordingly, it is not enough that a society seeks to prepare elite to undertake thinking and creativity on behalf of other groups, rather, the point is that members of "knowledge society" should be provided with fundamentals of science and that knowledge be available for all people (ALECSO, 2008).

Thus, the society will become, little by little, familiar with the achievements of science and technology and that each member turns to be an active factor having basics of systematic scientific thinking where his/her cognitive abilities get developed, consequently; his/her judgments and behaviors will be logical and constructive (Durant, Evans\& Thomas 1989).

The most important tool of our present time upon which we can depend for purpose of heading toward a reasonable level of scientific literacy is ICT (Arntzen, Krug, \& Wen, 2008; Mirskaya,2007). Such technology is not mere tools; rather, it provides information and adjusts our communications forms and even the ways of our thinking and creativity. 
How could we ensure access of all people to these information and intellectual resources and at the same time overcome social, cultural, and linguistic obstacles? How could we encourage process of placing contents on the internet where they are more varied and able to be a significant source for all people? What are the pedagogical opportunities provided by these new means of telecommunications? (Science in Information Society, 2005).

Regarding the academic area that is considered the gate of entering to distinct scientific literacy, the modern technology has redefined and reevaluated scientific literacy concepts and learning activities and entrusted teachers with new roles (Ovensi \& Alibabic, 2010). This has been achieved through the ability of modern technology to recycle and transmit texts, images, information, and knowledge across the world in a short time, which in turn, increases opportunities of learning and familiarizes people with all modern and sophisticated issues. Accordingly, providing opportunities for continuing learning and knowledge based on social and economical motivations, namely, cultural and scientific communication among people plus knowledge-based-economy requires qualified workforce that is able to develop its abilities, obtain more training, and be familiar with all recent developments related to its specializations in particular and various areas of science in general (Thoe, Abdul Rani, \& Fook, 2005).

Considering scientific literacy as a demographic characteristic of the society, most of studies in this field(Luu \& Freeman, 2010) show connection of this characteristic with ICT awareness of citizens and the nature of tasks they carry out using this technology.

These facts have pushed us to ask about various forms of ICT can be employed/implemented for purpose of reinforcing levels of scientific literacy which has become a basic demand within knowledge society, yet what made it difficult to answer such question is the relation of this objective with other aspects other than the technical aspect as desires and trends of individuals.

This study examines the following question:

How could we employ the ICT to reform scientific awareness and build a pioneering project of scientific literacy?

\section{Scientific Literacy}

The citizen's culture is the factor that determines his/her concerns, practices, behaviors, and priorities, and clarifies his/her intellectual grounds, scientific pillars, and self-motivations (Al Shibani, 2000). Thus, providing the citizen with scientific literacy is a necessity for development and growth. As a resultant, the scientific awareness becomes a main element of the public awareness, accordingly, success of scientific and research activities and technical development will become a collective trend in community.

In this context, the so-called "knowledge society" has become the most popular aspect designated upon the human society today, where the citizen who is able to adapt himself to live effectively in this society is the one who has the scientific literacy that enables him to use knowledge creatively to solve his everyday problems, to take the correct decisions and to develop of his living standards (Watters \& Ginns, 2000).

Being familiar with basic facts about outcomes of science, the scientific literacy is considered an integral part of the general culture and an important aspect in developing the youth's abilities for purpose of taking in science and technology concepts to be a routine daily behavior in life (Salameh, 2005; Harlen, 2006).

The U.S National Center for Education Statistics defines "scientific literacy" as perceiving and understanding scientific concepts and processes which the citizen needs to make decisions and participate in civil and cultural affairs and economic production rates (NAS, 1996).

The scientifically educated citizen is a person armed with skills such as (NAS, 1996; Prenzel, 2006):

- Understanding basic scientific facts and their meanings.

- Inquiring, searching, and answering the questions arising from curiosity about everyday experience.

- $\quad$ Describing, explaining, and predicting natural phenomena.

- $\quad$ Consciously reading articles in newspapers about sciences and involving in social discussions about validity of conclusions.

- Identifying scientific issues beyond the national and local decisions and carrying out explicit actions about them.

- $\quad$ Evaluating quality of scientific information based on its sources and the ways they are produced.

- Establishing and assessing the arguments that are based on evidences and applying the conclusions appropriately. 
The world has realized the importance of scientific and technological culture since early stages and it has carried out many considerable projects in order to develop effective scientific literacy among citizens. The most well-known projects are:

\section{1) 2061 Project}

This project, supported by the American Association for the Advancement of Sciences (AAAS), aims to upgrade standard of scientific literacy among the Americans and build a new American citizen. The project was built mechanism which believes the education can prepare the students to understand the way the world operates and help them to think independently and critically as well as enable them to enjoy life with responsibility as productive persons.

This project concentrates on the scientific vision toward the world, investigation methods, nature of scientific projects and mathematical process, relation between science and technology (AAAS, 1989).

\section{2) Japan Science and Technology Agency Project}

Here, this project aims to increase efficiency of scientific and technical awareness among commons especially the children and youth. It also includes holding scientific festivals, building video and multimedia libraries for sciences, and establishing scientific museums. Moreover, it aims to support studies of science and technology and create future leaders in terms of science and technology through (JST, 2012):

- Discovering and encouraging talented persons.

- Studying and applying advanced teaching programs.

- Developing and enhancing cooperative learning among schools and other institutions of society.

- Increasing activities and programs of rehabilitating teachers.

\section{3) (Chemistry is All Around Us) Project}

This project has been carried out in some European countries since 2011. It targeted developing successful strategies to enhance continuing learning and awareness of many scientific issues through utilizing ITC. Furthermore, this project helps develop educational methods and tools that assist students effectively in this regard for purpose of acquiring the skills necessary for scientific knowledge in the future. The persons in charge of the project believe that all its objectives can be achieved when increasing research collaboration between Faculty of Education and faculties of science, so the project focused on the providing teachers with training program during service and holding scientific exhibitions and conferences for students and parents. (Chemistry is All Around Us, 2001).

\section{ICT Tools}

Information and communication technology (ICT) has affected all areas of social, economic, and industrial life (Ovensi \& Alibabic, 2010), where the growth in all these areas has produced remarkable improvements concerning knowledge which in turn has made keeping up with and being familiar with all these kinds of knowledge produced by this movement a very difficult problem. Moreover, ICT is considered a key pillar to establish knowledge society since it is the main tool to spread out knowledge plus its role in developing, supporting, facilitating, and accelerating scientific and cultural research as wide as possible (Arab Knowledge Report, 2009).

Employment of ICT is almost the common factor among all programs and projects that scientifically try to build the educated society, where this technology provides sophisticated potentials, mechanisms, and programs to be used effectively to increase joining individuals in a continuing learning process.

In science teaching, ICT tools can be employed in order to improve learner's ability of understanding, using, and evaluating communication (Hoadley \& Bill, 1996; Volna. Et al, 2011) Where the student resorted to accessing information sources, carrying out processes of analysis and evaluation.ICT Provides opportunities for interaction with knowledge in various patterns and forms such as:

\subsection{On-Line Discussion}

ICT provides virtual learning environment (computer-based simulated classroom). The most important advantage of this technique is that it allows interactive scientific discussion and communication with others efficiently (Sorin, 2004; Sutherland, Marcus \& Jessup, 2005). It also shows its role in creating opportunities to develop thinking and presenting ideas to be criticized (Otero et al, 2005), developing problem-solving skills (Ferry et al.2005), and encouraging continuing self-learning (McDonald \& White, 2005). 
The most important advantages of the virtual environment on the internet are democracy and freedom of expression where all persons may discuss issues without any control or supervision (Bradford-Smith, Smith \& Boone, 2000; Swan, 2001; Scott \& Ryan, 2008; Kumar \& Vragov, 2009) . Furthermore, it allows students to easily communicate with their peers of students, teachers, scientists, researchers, industrialists, leaders, scientific centers, companies and clubs, etc ( Tinio, 2003; Osborne \& Dillion, 2010).

Computer-mediated Communication in teaching strategies and curricula planning may offer real and multiple learning opportunities through discussions that allow:

A. Granting students sufficient time for answer and dialogue.

B. Freedom of dialogue not subject to standards of the classroom.

C. Sharing ideas.

D. Later examination of ideas.

In order to get advantage from scientific discussion through (Social Networking Technologies), the users need various social an emotional skills in addition to the skills they use when meeting each other face to face (Jones \& Issroff, 2005).

(Osborne \& Dillon, 2010) has examined a set of studies to find out that the young people who have been taught according to synchronous and asynchronous online discussion have become interested in acquiring knowledge though the scientific groups that are interested in urgent scientific issues across the world.

\subsection{Digital Curriculum}

One of the most magnificent obstacles of development of education is the way upon which the curricula are carried out in schools and universities and not seeking to develop it (Shawer, Gilmore, \& Banks-Joseph, 2008; Shawer, 2010). Today, ICT provides an opportunity to develop curricula and their ways of implementation through E-curriculum or the so-called Digital curriculum which is a form of E-Teaching forms.). Communication is considered a digital one when it is carried out via the internet or through another digital mean like CDs. E-curricula represent the set of educational and scientific experiences provided to the learner through the enormous potentials provided by ICT, where the digital curriculum is considered a new form of communication between professionals and learners (Abbey, 2010; Kirkwood, 2011).

The digital curriculum employs several e-learning pattern through links with educational sites containing simulation programs of scientific concepts and phenomena that cannot be displayed or observed inside the classroom such as celestial bodies, earthquakes, and volcanoes (Ismail, 2010). Moreover, digital curricula have relations with (Tutorial Programs), Drill and Practice, Virtual interactive Lab which provides tools for labs of chemistry, biology, and physics to perform chemical reactions, physics experiments, in addition to using microscope to observe microscopic slices (Miller,2011).

In science teaching the web based remote control laboratory is a system that enables students to control real experiment from a remote location using internet and an ordinary web browser. This pattern of technology earns the Student benefits to explore many experiments not available in traditional labs, in addition to opportunities for communication and scientific knowledge (Cooper, Donnelly \& Ferreira, 2002)

The digital curriculum helps to achieve education objectives which mostly cannot be achieved in the traditional curricula as expected for many reasons, In addition, digital curriculum can easily build positive values and attitudes in the students toward scientific issues and phenomena. Thus, (Mckenzie, 2000) believes that the digital curriculum supports information culture of learners and helps to prepare them to technology-directed-world, if it is designed and developed properly.

\subsection{Multi-Form of ICT in Education}

ICT provides multi-tools such as include probes, spreadsheets, databases, internet search engines, word processors, simulations, presentation/multimedia tools, concept mapping tools and graphics tools (Alberta Learning, 2010 ) that can be employed through learning strategies for purpose of preparing learning opportunities in various ways.

\section{ICT Strategies in Science Teaching}

Since the anticipated objective of science teaching is preparing the young generation to have the sense and feeling about the ways upon which the world moves so that they can think independently and critically and be responsible as productive individuals in a world shaped with a culture based on science and technology (Kang, 2008). We notice that this objective can be achieved by building the culture that creates positive behavior and practice especially scientific literacy (Mirskaya, 2007). 
Thus, teaching science strategies plays a key role for establishing scientific literacy that distinguishes the citizen who is able to adapt himself to society of technology and knowledge (Rutherford \& Ahlgren, 1990) (NRC, 1996). This can be carried out through teaching strategies that give the students active role in social communication environment (Milne, 2007) (Linn, 1995) and self directed tasks develop strong motivations in them for purpose of continuing learning (Chee, et.al. 2011; Bidokht \& Assareh, 2011). To achieve this objective, a teacher who is able to build real learning opportunities and manage positive educational environment should be prepared. In addition, science curricula should be planned to work in the same context for purpose of matching learning activities with student's interests and encouraging their abilities to think freely and in advanced levels to be enthusiastic for continuing learning and having the scientific literacy (Marks \& Eilks, 2009).

The modern studies shows that the methodology of using ICT in teaching has strong impacts on scientific literacy level of the students (Luu \& Freeman, 2011). Undoubtedly, using effective educational strategies encourages creativity and innovation and builds trends of inquiry and investigation to build distinct scientific literacy for the students (Marks \& Eilks, 2009), unlike the common traditional teaching pattern which does not exceed the methods that just concentrate on retention of information by the students where teaching processes lack strategies and techniques that establish for distinct scientific literacy.

Concerning the pedagogical area, ICT provides a big opportunity to apply theories of learning that give the students a central role (Learner-Centered Pedagogy) when performing learning situations, equip them with strong motivations for continuing learning, and motivate them to search and investigate and eventually to gain a wide scientific literacy.

The high flexibility of ICT and diversity of its usages in teaching make it eligible to be the top priority in teaching process since it allows instructors to produce knowledge and share with others, it also provides opportunities of quick search and information retrieval in a well-organized method (Anderson, 2010).

Constructivism Theory concentrates on the student to perform real learning tasks that require using higher thinking skills with an exploratory context and through team work (Linn, 2000). (Computer Supported Collaborative Learning) performed in the context of knowledge integration environment greatly enhanced continuing learning and knowledge production.

Thus, Constructivism Theory pressures on designers of means and tools of ICT to shift from concentrating on traditional roles of transmitting knowledge and information to employing such means and tools to design constructive learning environment (Karagiorgi \& Symeou 2005; Solomonidou 2006)

ICT simulates authentic science learning through its tools that increase communication of the real world, reflective thinking, and problem-solving. Thus, the studies assert that the learning environment that employs ICT achieves Non-Linear Learning and increases learner's role which in turn facilitates the task of designing of constructive learning environment (tekos \& Solomonidou, 2009).

Accordingly, it is shown that employment of constructional teaching strategies during learning by using ICT is considered a key supporter that helps students acquire scientific culture with advanced levels.

\section{Positive Attitudes toward Scientific Knowledge}

Enabling students to use ICT tools help them to build positive attitudes towards scientific and environmental issues, animal projection, health, and prevention of epidemic diseases, besides, discussion are important to acquire critical thinking skills and upgrade a scale of positive values and trends toward learning and knowledge and ethics of science (Harris, Buchanana \& Walker, 2002). Concern for learning, acquiring knowledge, and continuous career development have a close relation with trends, interests, and motivations of the individual (Thoe, Rahihan, Abdul Rani \& Fook, 2005).

The great desire of the young to use modern technology and its services in all areas especially in the social one (Lenhart et al. 2008; Levin \& Arafeh 2002; Pew Internet \& American Life report 2002), shows the effect of ICT upon their trends and emotions. Thus, access to the internet has become the most important concern of this generation since it represents their wide world through providing them with freedom of expression, dialogue, and knowledge of others' ideas and culture (Mehanna, 1995; Dinger \& Sashinkayas, 2011).

The multiplicity and diversity forms of knowledge displayed by ICT (text, simulation, movies, games, discussion ....) increase the desire of students to learn attain and retain knowledge where this is consistent with their wishes and interests. 


\section{Method}

The study was initiated at the first semester in the academic year 2011-2012 at Al-Hussein Bin Talal University in Jordan. The researcher tested the scientific literacy about the concepts of space and astronomy for the control group consisting of (123) students in science college, who have studied the course of Astronomy and Space Physics by the traditional way. The test has been prepared to measure the level of scientific literacy about the space and astronomy concepts, and had all the statistical treatments, where the reliability coefficient was (0.87)

At the beginning of the second semester, experimental group were selected in the science college consisting of (121) students, and it was to ensure parity for the two groups. The colleagues who taught the course to the experimental group were trained and informed about the objectives and methodology of the study and familiarized them with ICT tools. Also, they were briefed on the most important programs and technologies related to teaching course Astronomy and Space Physics including:

\section{1- E-mails}

2- Facebook \& Twitter

3- On- line conference

4- Learning Site:

- YouTube-Cosmo Learning

- http://www.space.com/

- http://www.universetoday.com/

- http://www.astronomynow.com/

- http://astronomy101.jpl.nasa.gov/

The colleagues also had been trained on how to teach through employment of ICT using planning an educational tasks and worksheets by exploratory context at the end of the semester, students took the same test.

\section{Result}

The table 1 shows the results of the two groups at scientific literacy:

Table 1. Averages and standard deviations of the level of scientific literacy among the two groups (experimental and control)

\begin{tabular}{llcc}
\hline Group & N & Mean & Std. Deviation \\
\hline Control & 123 & 11.8943 & 5.12438 \\
Experimental & 121 & 21.3967 & 6.08479 \\
\hline
\end{tabular}

In order to identify the statistical significance of the differences among means. T-test was used as shown in the table 2. It was found that the impact of teaching using ICT was positive at the level of scientific literacy

Table 2. T-Test

\begin{tabular}{lllc}
\hline & t & df & Sig. (2-tailed) \\
\hline Equal variances assumed & -13.203 & 242 & 0.000 \\
Equal variances not assumed & -13.184 & 233.880 & 0.000 \\
\hline
\end{tabular}

The colleagues who have ran the teaching process using ICT, confirmed the employing ICT in physics teaching was effective for acquisition of scientific concepts and growth of scientific knowledge among students. Here are some of their comments. 


\section{Teacher A:}

The students' motivation to learn was high when teaching through ICT tools compared to the usual way, as one of the most important pros have appeared keen students on self and continuous learning.

\section{Teacher B:}

The implementation of the learning tasks in the teamwork communication pedagogy through electronic networking sites was a major cause in the interest of students to learn more.

\section{Teacher C:}

Employing ICT tools in teaching physics line with the interests of this generation of students and make them employ these techniques to acquire things that develop their thinking.

The study results confirmed the strong relation between usage of ICT by the individuals and their scientific literacy (Wu \& Glaser, 2004). However, as it turns out the nature of this relation depends on the way of using ICT in learning and the level of skill to use it as well as the nature of learning tasks entrusted to the students (Luu \& Freeman, 2011).

\section{Discussion}

Developing scientific literacy and establishing a scientific awareness requires a new relation between the learner and knowledge sources in order to identify the most useful things for learning, the most effective ways to acquire such things, the best sources, and the best way the modern technology can help in this regard (McNair, 2000).

ICT is considered a key role for continuing learning, since it ensures a quick access to every new knowledge around the world regardless of spatial and temporal limits (McNair, 2000). Accordingly, ICT provides an increasing range of tools to treat digital data and access to a wide and varied set of contents that support the information age (McFarlane \& Sakellarion, 2002) which makes this technology an important tool for people and societies in order to develop their scientific and cultural abilities and be able to keep up with developed countries.

However, in order to get the most advantages from this technology to develop the culture of citizens and increase their abilities to produce scientific knowledge, education institutions should comply with the correct methodology of using ICT in learning processes through constructive learning strategies within social contexts to perform real tasks (Arntzen, Krug \& Wen, 2008; Luu \& Freeman, 2011).

ICT provides many tools and patterns that can be utilized through constructive learning strategies in teaching science, where the student can perform several tasks and activities and be responsible for his learning process. These tools can achieve constructive social learning environment like ( Chat/Online Conference) as well as getting advantage form the increasing usage of this technology by the students especially social networking sites (Facebook, Twitter, Fliker, Youtube, Skype) (Ito et al, 2008) besides the constant use of mobiles, I-Phone, and I-Pad, consequently, to overcome the key obstacles facing ambitions of the people responsible for education and upgrade scientific literacy level of the citizens (Figure.1), namely, forming the real motivations and establishing positive trends in the students to gain more scientific knowledge. (Vanderlinde. et al, 2010) 


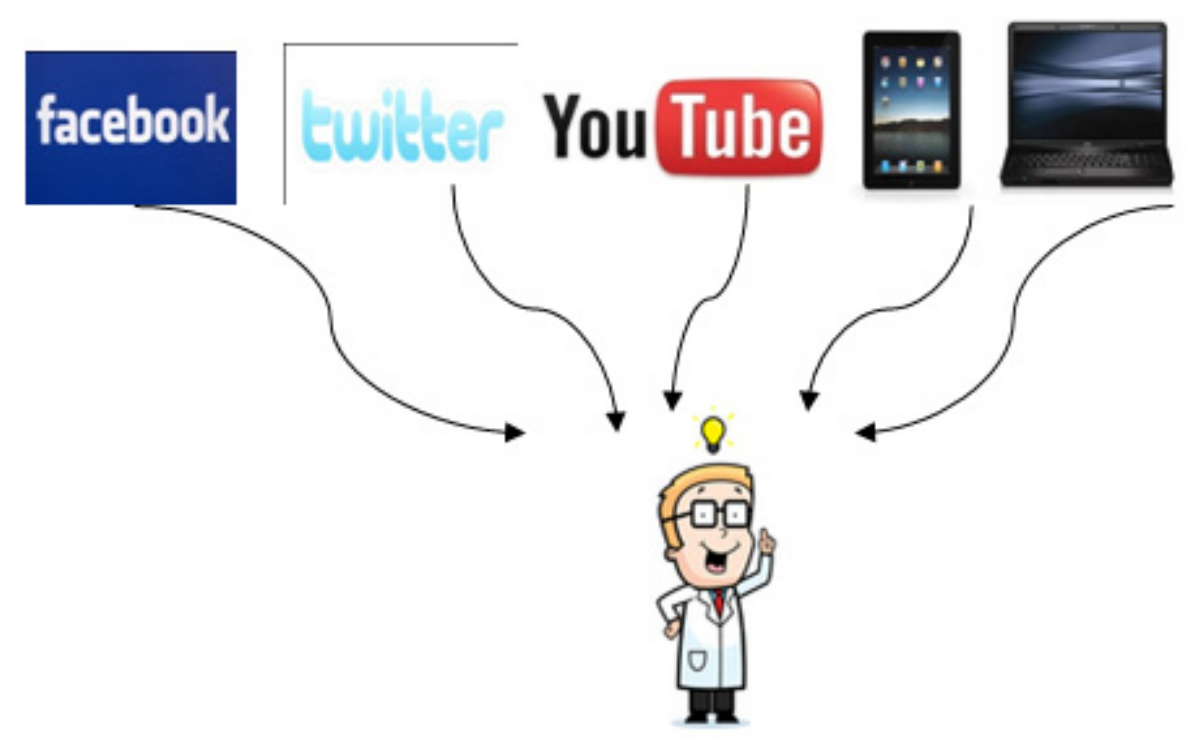

Figure 1 . Scientifically educated citizen

The relation of ICT with students' motivations and trends has central role in developing scientific literacy and encouraging the continuing learning, as this technology has a deep impact on learning process and content and building positive trends toward learning when performing learner-centered approach and preparing opportunities of collaborative and interactive learning (Leu et al. 2004; Dinevski \& Kokol, 2004).

To conclude, we come up with a model (Figure 2) that helps teachers in the various stages to give their students an advanced level of scientific knowledge.

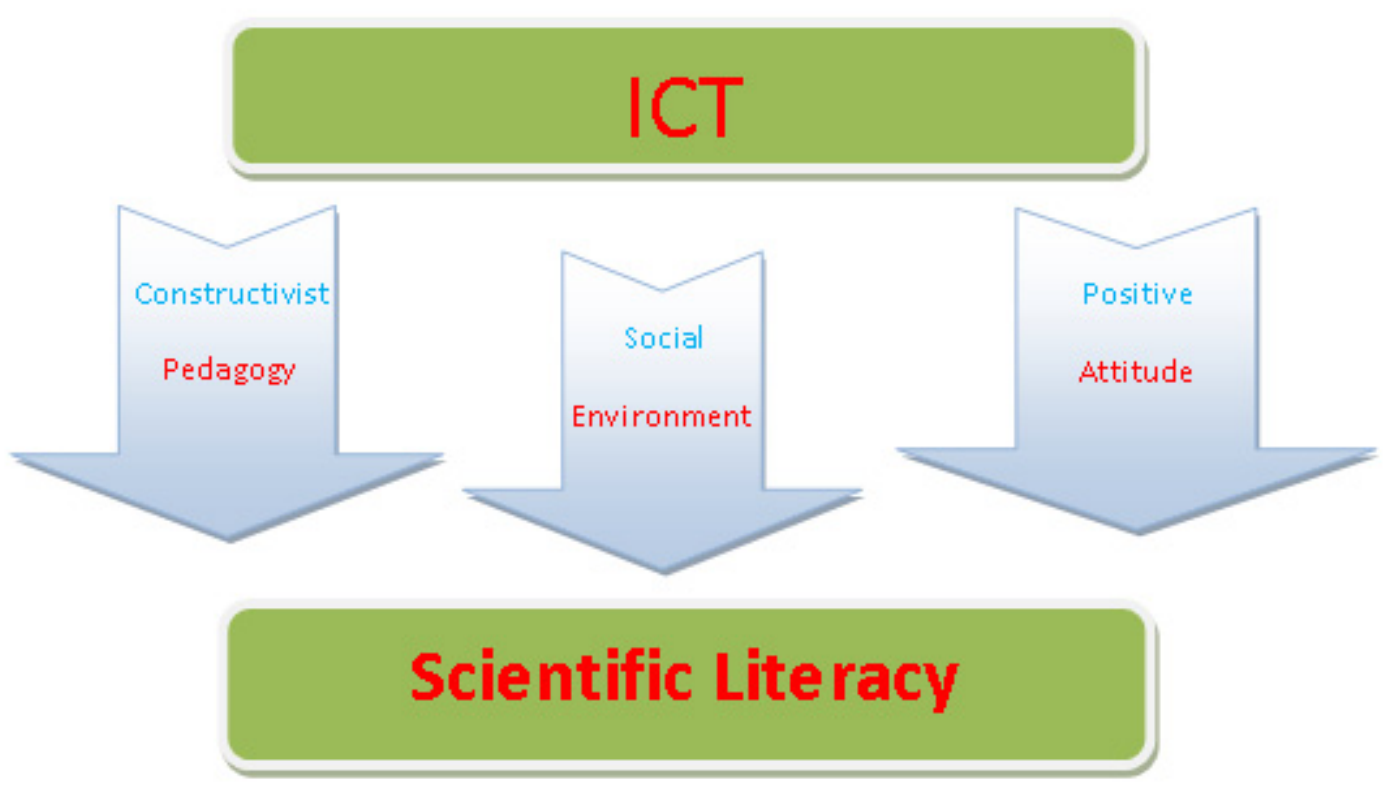

Figure 2. PEA model 
The PEA model depends on the use of ICT in the teaching of science based on the following three requirements:

1. Using ICT in a way consistent with the tendencies of the Students and their attitudes.

2. Constructing educational content based on the constructivist theory of learning.

3. Providing a social learning environment.

Having shown the model, must promoting a scientific literacy through rebuilding and planning various curricula especially science curricula according to the strategy of using ICT in teaching sciences that is based on Constructivist Theory (Staples et al., 2005). The model is expected to include training to prepare the teachers and faculty members in universities to apply such educational strategy. To sum up, the implementation of a leading scientific literacy requires designing the appropriate learning environment through providing supplies, programs, networks, and the classrooms equipped with new technologies that enable communication with the world easily and quickly.

\section{References}

Abbey, E. (2010). The Digital Curriculum. Retrieved January 20, 2012, from http://www.itec-ia.org/documents/filelibrary/2009_conference/handouts/The_Digital_Curriculum_31F3935 ECBABA.pdf

Adubifa, A. (2003). Making science and technology work for the poor and for sustainable development in Africa: parliamentary documentation. United Nations. Economic and Social Council; United Nations. Economic Commission for Africa; UN. ECA Committee on Sustainable Development Meeting (3rd: 2003, Oct. 7 - 10: Addis Ababa, Ethiopia) (2003-08).

Alberta Learning. (2010). Evaluation of the Canadian Space Agency Tele-Learning Program - Executive Summary. Summary of Final Research Report. Retrieved February 16, 2012, from http://education.alberta.ca/admin/technology/research.aspx

AlShibani, K. M. (2000). Scientific culture The Key of technical. Journal of Science and technical, 14(55). [Web $\log$ post]. $\quad$ Retrieved $\quad$ March $8, \quad$ 2012, from http:/just4u2008.arabblogs.com/\%D9\%85\%D8\%AF\%D9\%88\%D9\%86\%D8\%A7\%D8\%AA\%D9\%8A/arc hive/2008/2/483374.html

American Association for the Advancement of Science (AAAS). (1989). Science for all Americans. Oxford University Press: New York.

Arntzen, J., Krug, D., \& Wen, Z. (2008). ICT literacies and the curricular conundrum of calling all complex digital technologies "Tools". International Journal of Education and Development using ICT, 4(4), 6-14. Retrieved from http://ijedict.dec.uwi.edu/viewarticle.php?id=571

Anderson, J. (2010). ICT Transforming Education. UNESCO Bangkok. Asia and Pacific Regional Bureau for Education.

Arab Knowledge Report. (2009). United Nations Development Programme Retrieved January 8, 2012, from http://arabstates.undp.org/contents/file/newfiles/AKR09_E/Intro.pdf

Arab League Educational, Cultural and Scientific Organization. ALECSO. (2008). Draft of spreading scientific and technical culture in the Arab World. Retrieved January 12, 2012 from http://www.alecso.org.tn/images/stories/fichiers/science/studies/Prog01.pdf

Bidokht, M. H., \& Assareh, A. (2011). Life-long learners through problem-based and self directed learning. Procedia Computer Science, 3, 1446-1453. http://dx.doi.org/10.1016/j.procs.2011.01.028

Bradford-Smith, S., Smith, S., \& Boone, R. (2000). Increasing access to teacher preparation: The effectiveness of traditional instructional methods in an online learning environment. Journal of Special Education Technology, 15(2), 37-50.

Chee, T. N., Divaharan, C., Tan, L., \& Mun, C. H. (2011). Self-directed Learning with ICT: Theory, Practice and assessment. Ministry of Education .Educational Technology Division North Buona Vista Drive - singapore 138675.

Chemistry is All Around Us. (2001). The "Chemistry is All Around Us" Project. Retrieved March 2, 2012, from http://www.chemistry-is.eu/ 
Cooper, M., Donnelly, A., \& Ferreira, J. (2002). Remote Controlled Experiments For Teaching Over the internet: a comparison of approaches developed in the pearl project. ASCILITE 2002, 8-11 December 2002, Auckland, New Zealand.

Dincer, S., \& Sahinkayasi, Y. (2011). A Cross-Cultural study of ICT Competency, Attitude and Satisfaction of Turkish, Polish and Czech University Students. The Turkish Online Journal of Educational Technology, 10(4), 31-38.

Dinevski, D., \& Kokol, P. (2004). ICT and LifeLong Learning. Retrieved February 5, 2012, from http://www.eurodl.org/materials/contrib/2004/Dinevski.html

Durant, J., Evans, G. A., \& Thomas, G. P. (1989). The Public Understanding of Science. Nature, 340, 11-14. http://dx.doi.org/10.1038/340011a0

Ferry, B., Kervin, L., Cambourne, B., Turbill, B., Hedberg, J., \& Jonassen, D. (2005). Incorporating real experience into the development of a classroom-based simulation. Journal of Learning Design, 1(1), 22-32. Retrieved January 12, 2012 from www.jld.qut.edu.au/S

Harlen, W. (2006). Primary Science Education for the 21stCentury. In W. Harlen (Ed.), ASE Guide to Primary Science Education (pp. 3-9). HertsAL109AA: ASE.

Harris, B., Buchanan, J., \& Walker, S. L. (2002). Evaluation report on the global education project Geography Teachers Association of Victoria. NSW: Univ. of Western Sydney.

Hoadley, C. M., \& Bill, P. (1996). The Design of Digital Resources to Enhance Lifelong Learning. D-Lib Magazine. http://dx.doi.org/10.1045/september96-hoadley

Ismail, M. R. (2010, March 17). Digital Curriculum. [Web log post]. Retrieved from http://magdyscienceedu.blogspot.com/2010/12/digital-curriculum.html

Ito, M., Horst, H. A., Bittanti, M., Boyd, D., Herr-Stephenson, B., \& Lange, P. G., et al. (2008). Living and Learning with New Media: Summary of Findings from the Digital Youth Project. The John D. and Catherine T. MacArthur Foundation Series on Digital Media and Learning. Retrieved from http://www.macfound.org/atf/cf/\%7BB0386CE3-8B29-4162-8098-E466FB856794\%7D/DML_ETHNOG_ WHITEPAPER.PDF

Japan Science and Technology Agency (JSTA). (2012). Promoting Communication on Science and Technology. Retrieved from http://rikai.jst.go.jp/eng/

Jones, A., \& Issroff, K. (2005). Learning technologies: Affective and social issues in computer-supported collaborative learning. Computers and Education, 44(4), 395-408. http://dx.doi.org/10.1016/j.compedu.2004.04.004

Kang, N. (2008). Learning to teach science: Personal epistemologies, teaching goals, and practices of teaching. Teaching and Teacher Education, 24, 478-498. http://dx.doi.org/10.1016/j.tate.2007.01.002

Karagiorgi, Y., \& Symeou, L. (2005). Translating constructivism into instructional design: potential and limitations. Educ Technol Soc, 8(1), 17-27.

Kirkwood, P. (2011). Shaping the curriculum: The power of a library's digital resources. Computers in Libraries, 31(4). Retrieved from http://www.questia.com/library/1G1-256071241

Kumar, N., \& Vragov, R. (2009). Active citizen participation using ICT tools. Communications of the ACM, 52(1), 118-121. http://dx.doi.org/10.1145/1435417.1435444

Laugksch, C. (2000). Scientific Literacy: A Conceptual Overview. In John Wiley, \& Sons, Inc. Sci. Ed, 84(1), 71-94. http://dx.doi.org/10.1002/(SICI)1098-237X(200001)84:1<71::AID-SCE6>3.0.CO;2-C

Lenhart, A., Arafeh, S., Smith, A., \& Rankin Macgill, A. (2008, April 24). Writing, technology and teens: Pew Internet \& American life project. Retrieved February 1, 2012, from http://www.pewinternet.org/pdfs/PIP_Writing_Report_FINAL3.pdf

Leu, D. J., Kinzer, C. K., Coiro, J. L., \& Cammack, D. W. (2004). Toward a theory of new literacies emerging from the Internet and other information and communication technologies. In R. B. Ruddell, \& N. J. Unrau (Eds.), Theoretical Models and Processes of Reading (5th ed.) (pp. 1570-1613). Newark, DE: International Reading Association. 
Levin, D., \& Arafeh, S. (2002). The Digital Disconnect: The Widening Gap Between Internet-Savvy Students and Their Schools [Electronic Version]. Retrieved March, 17, 2012 from http://www.pewinternet.org/pdfs/PIP_Schools_Internet_Report.pdf

Linn, M. C. (1995). Designing computer learning environments for engineering and computer science: The scaffolded knowledge integration framework. Journal of Science Education and Technology, 4(2), 103-126. http://dx.doi.org/10.1007/BF02214052

Linn, M. C. (2000). Designing the knowledge integration environment. International Journal of Science Education, 22(8), 781-796. http://dx.doi.org/10.1080/095006900412275

Luu, K., \& Freeman, J. (2011). An analysis of the relationship between information and communication technology (ICT) and scientific literacy in Canada and Australia. Computers \& Education, 56(4), 1072-1082. http://dx.doi.org/10.1016/j.compedu.2010.11.008

Marks, R., \& Eilks, I. (2009). Promoting Scientific Literacy Using a Socio-critical and Problem-Oriented Approach to Chemistry Teaching: Concept, Examples, Experiences. International Journal of Environmental \& Science Education, 4(3), 231-245.

McDonald, L., \& White, P. (2005). Blended learning. In Clark, J., \& Maguire, M. (Eds.), Challenges for the profession: Perspectives and directions for teachers, teaching and teacher.

McFarlane, A., \& Sakellariou, S. (2002). The role of ICT in science education. Cambridge Journal of Education, 32(2), 219-232. http://dx.doi.org/10.1080/03057640220147568

McKenzie, J. (2000). Beyond Technology: Questioning, Research, and the Information Literate School. Bellingham, WA: FNO Press.

McNair, S. (2000). The emerging policy agenda. In: OECD-CERI. Learning to bridge the digital divide. Paris: OECD.

Mehanna, W. (1995). Education and Information Technology in the Arab Countries: Issues and Trends-Yearbook IV. A Case Study of Interactions with, Attitudes to, and Perceptions of Online Learning. Lebanese association for educational studies.

Miller, J. (2011). Customizing Curriculum with Digital Resources. The Science Teacher, 78(7), 46-50.

Milne, I. (2007). What scientific literacy. Retrieved from http://www.sciencepostcards.com/sciencelinks/science_literacy_links/science_literacy_links.html

Mirskaya, E. (2007). National Scientific Communities in the Globalized World: Global ICTs as a Tool of Modernization among the Russian Academic Community. PGDT, 6(4), 557-566. Retrieved from www.brill.nl/pgdt

National Academy of Sciences. NRC. (1996). National Science Education Standards (Report). National Academy Press.

Osborne, J., \& Dillon, J. (2010). Good practice in Science Teaching: What research has to say. McGraw Hill. Open University Press.

Otero, V., Peressini, D., Meymaris, K., Ford, P., Garvin, T., \& Harlow, D., et al. (2005). Integrating technology into teacher education. A Critical framework for implementing reform. Journal of Teacher Education, 56(1), 8-23. http://dx.doi.org/10.1177/0022487104272055

Ovensi, K., \& Alibabic, S. (2010). Implications of ICT in the Continuing Professional Education and Learning. 4th International Conference "Education Facing Contemporary World Issues", Piteşti, Romania, 2010, October, 8th - 9th Procedia - Edu -World 2010.

Pew Internet \& American Life report. (2002). Use of the internet at major life moments. Retrieved March, 23, $2012 \mathrm{http}: / /$ www.pewinternet.org/reports/toc.asp?Report $=58$

Prenzel, M. (2006). Scientific Literacy in PISA British Council International Seminar on Scientific Literacy and its implications for schools. September, 2006 York.

Rutherford, F. J., \& Ahlgren, A. (1990). Science for all Americans. New York: Oxford: Oxford University Press.

Salameh, S. (2005). Scientific culture and prepare for the future. Retrieved from http://cms.aawsat.com/leader.asp?section=3\&article=309938\&issueno $=9716$ 
Scott, A., \& Ryan, J. (2008). Integrating technology into teacher education: How online discussion can be used to develop informed and critical literacy teachers. Teaching and Teacher Education, 24(2008), 1635-1644. http://dx.doi.org/10.1016/j.tate.2008.02.012

Shawer, S., Gilmore, D., \& Banks-Joseph, S. (2008). Student cognitive and affective development in the context of classroom-level curriculum development. Journal of the Scholarship of Teaching and Learning, 8(1), $1-28$.

Shawer, S. (2010). Classroom-level curriculum development: EFL teachers as curriculum-developers, curriculum-marks and curriculum-transmitters. Teaching and Teacher Education, 26(2), 173-184. http://dx.doi.org/10.1016/j.tate.2009.03.015

Solomonidou, C. (2006). New trends in educational technology. Constructivism and new learning environments. Metaihmio editions, Athens (in Greek).

Sorin, R. (2004). Webfolio: An online learning community to help link university studies and classroom practice in preservice teacher education. Australasian Journal of educational Technology, 20(1), 101-113. Retrieved from http://ezproxy.acu.edu.au:2434/ajet/ajet20/sorin.htmlS

Staples, A., Pugach, M. C., \& Himes, D. (2005). Rethinking the technology integration Challenge: Cases from three urban elementary schools. Journal of Research on Technology in Education, 37(3), 285-311.

Sutherland, L., Marcus, G., \& Jessup, A. (2005). From face-to face to blended learning: issues and challenges in redesigning a professional course. In Brew, A., \& Asmar, C. (Eds.), Higher education in a changing world: Proceedings of the 2005 annual international conference of the Higher Education Research and Development Society of Australasia (HERDSA) 3-6 July.

Swan, K. (2001). Virtual interaction: Design factors affecting student satisfaction and perceived learning in asynchronous online courses. Distance Education, 22(2), 306-331. http://dx.doi.org/10.1080/0158791010220208

Tekos, G., \& Solomonidou, C. (2009). Constructivist learning and teaching of optics concepts using ICT tools in Greek primary school: A pilot study. Journal of Science Education and Technology, 18(5), 415-428. http://dx.doi.org/10.1007/s10956-009-9158-2

Thoe, N., Abdul Rani, R., \& Fook, F. (2005). Developing Scientific and Technological Literacy (STL) towards Lifelong Learning: A Case Study for Continuing Professional Development (CPD). Malaysian Online Journal of Instructional Technology, 2(2), 137-147.

Tinio, V. (2003). ICT in Education, United Nations Development Programme.

Vanderlinde, R., van Braak. J., \& Tondeur, J. (2010). Using an online tool to support school-based ICT policy planning in primary education. Journal of Computer Assisted Learning, 26, 434-447. http://dx.doi.org/10.1111/j.1365-2729.2010.00358.x

Volna, M., Latel, F., Kainzova, V., \& Riha, J. (2011). 112 Modern tools for popularization and motivation students in Physics teaching. Problems of education in the 21st century, 31, 2011.

Wagner, D., \& Kozma, R. (2005). New Technologies for Literacy and Adult Education: A Global Perspective. (2005). Education on the move. UNESCO Publishing. Published in 2005 by the United Nations Educational, Scientific and Cultural Organization 7, place de Fontenot F-75352 Paris 07 SP.

Watters, J. J., \& Ginns, I. S. (2000). Developing motivation to teach elementary science: Effect of collaborative and authentic learning practices in preservice education. Journal of Science Teacher Education, 11(4), 277-313. http://dx.doi.org/10.1023/A:1009429131064

Wu, Z., \& Glaser, R. E. (2004). Software for the synergistic integration of science with ICT education. Journal of Information Technology Education, 3, 325-339.

\section{Copyrights}

Copyright for this article is retained by the author(s), with first publication rights granted to the journal.

This is an open-access article distributed under the terms and conditions of the Creative Commons Attribution license (http://creativecommons.org/licenses/by/3.0/). 